Review

\title{
Empirical Research of Public Acceptance on Environmental Tax: A Systematic Literature Review
}

\author{
Izlawanie Muhammad ${ }^{1} * \mathbb{1}$, Norfakhirah Nazihah Mohd Hasnu ${ }^{1}$ and Paul Ekins ${ }^{2}$ \\ 1 Faculty of Economics and Muamalat, Universiti Sains Islam Malaysia, Bandar Baru Nilai, \\ 71800 Nilai, Malaysia; kirahnazihah@gmail.com \\ 2 Institute for Sustainable Resources, University College London, London WC1E 6BT, UK; p.ekins@ucl.ac.uk \\ * Correspondence: izlawanie@usim.edu.my
}

check for updates

Citation: Muhammad, I.; Mohd Hasnu, N.N.; Ekins, P. Empirical Research of Public Acceptance on Environmental Tax: A Systematic Literature Review. Environments 2021, 8, 109. https://doi.org/10.3390/ environments 8100109

Academic Editor: Spyros Foteinis

Received: 17 August 2021

Accepted: 10 October 2021

Published: 15 October 2021

Publisher's Note: MDPI stays neutral with regard to jurisdictional claims in published maps and institutional affiliations.

Copyright: (C) 2021 by the authors. Licensee MDPI, Basel, Switzerland. This article is an open access article distributed under the terms and conditions of the Creative Commons Attribution (CC BY) license (https:/ / creativecommons.org/licenses/by/ $4.0 /)$.

\begin{abstract}
Several international organizations such as the Organization for Economic Co-operation and Development (OECD), United Nations (UN), and World Bank recommend that policymakers implement an environmental tax to reduce climate change, protect the environment and gain more income for governments. Effectiveness of the policy depends on a carefully designed framework, which essentially adopts the social and economic contextual of a country and public support. Researchers have been focusing on examining the factors that influence public acceptance of an environmental tax. This paper aims to systematically review the empirical studies using the RepOrting Standards for Systematic Evidence Syntheses (ROSES) protocol. The information is relevant for policy makers in designing a feasible and acceptable carbon tax policy. Furthermore, the paper provides suggestions for future research. Related articles were selected using two leading databases, namely Scopus and Science Direct, and one supporting database, namely Google Scholar. Thematic analysis was conducted on 60 articles and four main themes were derived with 32 subthemes. The analysis indicates that people are more supportive when they (i) are well informed about a policy's effectiveness and the policy content, particularly the use of revenue, (ii) have high trust in the government, (iii) have a positive attitude toward protecting the environment, (iv) perceive the policy is fair in terms of costs distribution and social sharing, and (v) are concerned about the climate change issue.
\end{abstract}

Keywords: public acceptance; environmental tax; systematic literature review; empirical research; RepOrting Standards for Systematic Evidence Syntheses; ROSES

\section{Introduction}

Social dilemmas and a lack of collective actions are commonly understood as the causes of environmental issues, including pollution, climate change, and depletion of common pools of resources [1]. Responding to this, protecting the earth's climate has become a vital transformational agenda in many countries that needs a resolute and enduring commitment [2]. The Paris Agreement is an example of a legally binding international treaty that aims to reduce climate change issues by targeting a limit between $1.5^{\circ} \mathrm{C}$ and $2{ }^{\circ} \mathrm{C}$ of global mean temperature [3]. These targets are above pre-industrial levels, and the limitations serve to avoid the impacts of climate change on humanity. To achieve the target, the agreement denotes several strategies to be adopted by the government and the public. The environmental tax is one of the strategies strongly recommended by many international bodies, including the Organization for Economic Co-operation and Development (OECD), United Nations, and World Bank.

Environmental tax will lead to changes in public behavior for the better by increasing the cost of activities detrimental to the environment while encouraging the adoption of innovative and greener alternatives [4]. Examples of environmental tax are carbon tax, fuel tax, electricity tax, motor vehicle tax, and waste treatment tax. Moreover reducing environmental issues, the policy will also increase the economic and social development of a country to provide better facilities to the public and invest in green technologies. 
An increase in revenue, even a slight one percent of gross domestic product (GDP), will significantly assist the government in recovering from the COVID-19 crisis and improving the country's economic and social development [5]. However, the public is often resistant to the taxes implemented by the government. Though public attitudes are by no means the only influence on environmental tax outcomes, a better understanding of the public opposition is required to facilitate the implementation of the government's efforts [6]. Guidelines on implementing environmental tax highlight the importance of understanding public responses before and after policy execution [7,8].

Building public support is crucial for ensuring effective and sustained environmental tax. Without the support of firms and households, the policy is likely to face significant obstacles at the implementation stage and may not last long enough to have the desired economic, environmental, or fiscal impacts [9]. On numerous occasions, environmental tax proposals are rejected by the public, such as the cases in Switzerland, Washington State, France, Canada, and Australia [10]. Such circumstances led to many studies on the public attitudes toward and acceptance of environmental tax. The current study adopted a rigorous systematic review to examine the relationship between public acceptance and environmental tax. Outcomes from this study will inform policymakers on the factors that influence public acceptance and rejection of environmental tax, which assist governments in constructing environmental tax policies that are acceptable to the public. The outcomes will also facilitate future researchers by providing a comprehensive selection of variables that have been tested and their results. Suggestions for future research are provided at the end of this paper.

\section{Methodology}

\subsection{Review Protocol and Research Question}

The present study was guided by the RepOrting Standards for Systematic Evidence Syntheses (ROSES) developed by Haddaway et al. [11]. ROSES is specifically designed for the environmental management field. The standards serve to ensure that researchers offer the correct information with an adequate level of detail. In the review protocol, the first step is to formulate the research questions for the review, followed by three subprocesses: identification, screening (inclusion and exclusion criteria), and eligibility. The subsequent step is to assess the quality of the selected articles, and the final step is to abstract the data using data analysis and validation. The research question posed by the current study is "What are the factors that influence public acceptance of environmental tax?" Figure 1 illustrates the flow diagram of the methodology.

\subsection{Systematic Search Strategies}

The first step of the systematic search was to identify the search synonym, terms, and variations for the main keywords related to a study [12]. The keywords were expanded by referring to the terms used in past studies, online thesaurus, and keywords suggested by Scopus. Scopus and Science Direct were used as the primary databases as they are among the 14 most suitable databases for a systematic review [13]. Google Scholar was then searched following the suggestion by Haddaway et al. [14] and Shaffril et al. [15]. Compared to other discovery tools, Google Scholar can produce numerous results, though the results can be repetitive [15].

The research string used from each database is shown in Table 1. Scopus does not impose Boolean limits, thus allowing the researchers to put as many synonyms as possible. Science Direct allows only eight Boolean connectors, and therefore, the researcher had to select the most related synonyms for the research string. Google Scholar only captures the inverted commas, and therefore, a general research string was used. The first screening process from the databases was conducted simultaneously by limiting articles to the following criteria: (i) published between 2000 and 2020, (ii) published in English, and (iii) full papers in journals. The total numbers of articles retrieved from Scopus and Science Direct were 90 and 16, respectively. The results from the Google Scholar search were filtered 
in terms of the time range, which resulted in 592 articles. In total, 698 articles were collected in the identification stage.

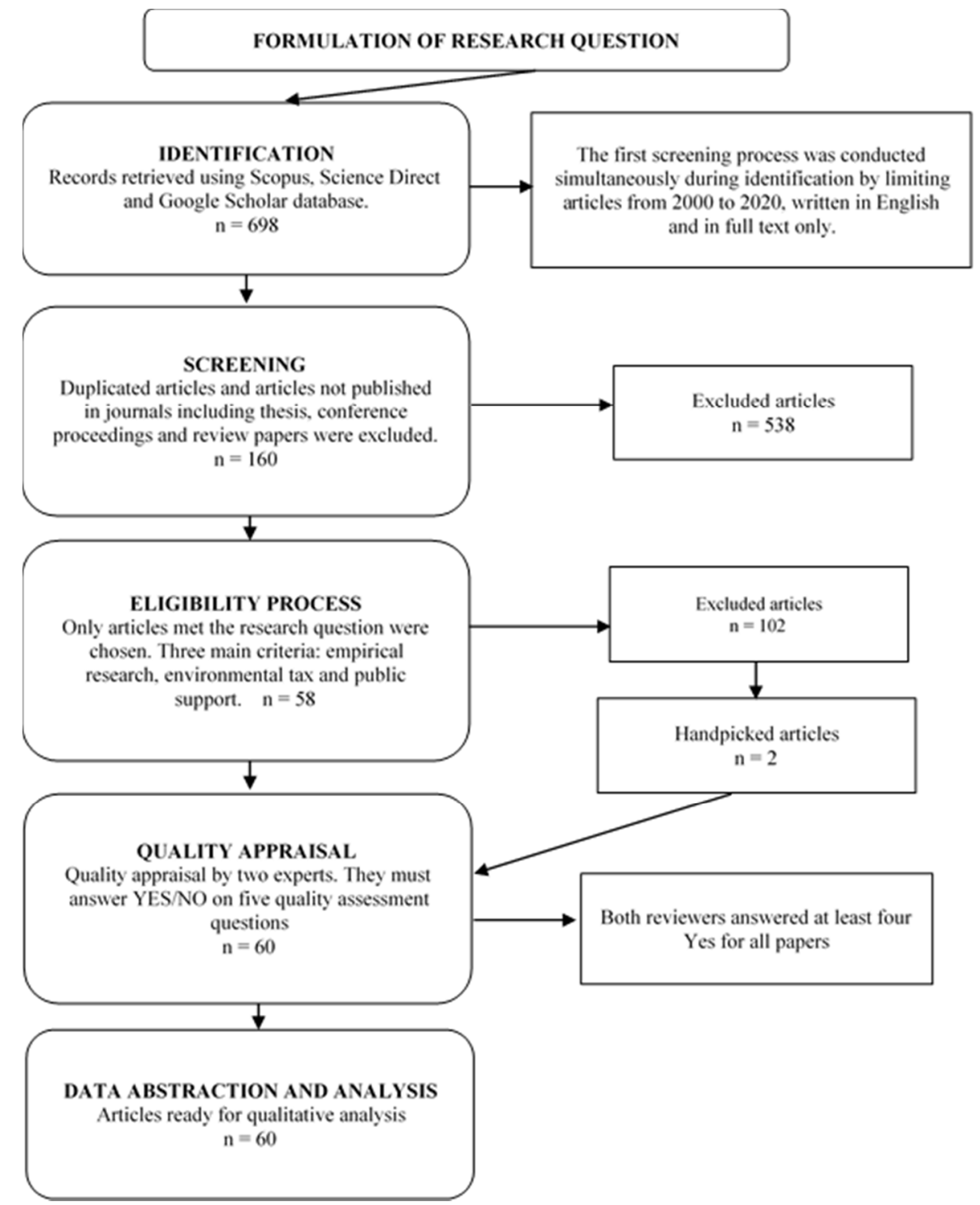

Figure 1. Flow Diagram of the Methodology.

Table 1. Search String.

\begin{tabular}{|c|c|}
\hline Database & Search String \\
\hline Scopus & 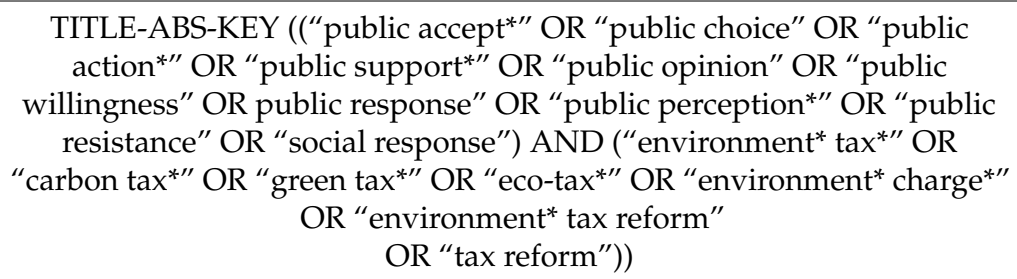 \\
\hline Science Direct & $\begin{array}{c}\text { TITLE-ABS-KEY (("public acceptance" OR “public support" OR “public } \\
\text { willingness" OR "public perception") AND ("environmental tax" OR } \\
\text { "carbon tax" OR "environmental tax reform" OR “environmental } \\
\text { charges" OR “green tax")) }\end{array}$ \\
\hline Google Scholar & "Public acceptance" “environmental tax" \\
\hline
\end{tabular}


During the screening process, the authors excluded duplication and articles not published in journals, such as theses, newspapers, conference proceedings, and review papers. A total of 538 papers were excluded, leaving only 160 articles shortlisted for the eligibility process. The authors manually monitored the retrieved articles in the eligibility process to ensure they related to the research questions. This process involved reading the title, abstract, research methodology, and results of the articles. Only empirical studies on public acceptance of environmental tax studies were selected, including articles concerning willingness to pay (WTP). A total of 102 papers were excluded because the studies were non-empirical and not focused on non-environmental tax policy, for example, emission trading system and subsidies. Ultimately, only 58 articles were selected. In addition to the database search, the authors manually picked two additional papers through reference searching from the most recent published papers (i.e., [16-23]) Thomas et al. [24] suggest that a combination of manual and database searching can present extensive improvement of systematic reviews. The search ultimately resulted in 60 articles for the quality appraisal process.

\subsection{Quality Appraisal}

The titles and authors of the 60 papers were listed in Microsoft Excel, and the full papers were renamed and saved in a cloud file. The cloud file was shared with two experts for quality assessment. The purpose of the quality appraisal was to assess the quality of the contents of the articles. Five questions were addressed to the experts: (1) Does the article's primary aim relate to the research question? (2) Is the article empirical research? (3) Does the article clearly define the research methodology adopted? (4) Does the research apply an acceptable statistical/qualitative analysis method? (5) Does the paper clearly explain the results? The queries sought responses of either 'yes, no, or cannot tell' for each question. The quality of each paper was ranked either 'low, medium, or high' [25] based on the number of 'yeses' it received from the respondents. A high-quality article is noted to have four to five 'yeses', a medium-quality article has at least three 'yeses', and a low-quality article has one or two 'yeses'. Both reviewers ranked all papers as high quality, and therefore, the articles were considered eligible for data abstraction and analysis process.

\subsection{Data Abstraction and Analysis}

An integrative review process was applied to allow diverse research designs (quantitative, qualitative, mixed-method) to be included in the review. Combining qualitative and mixed-method techniques enabled the authors to conduct iterative comparisons across the primary data sources [26]. The 60 articles were read comprehensively, particularly the abstracts, results, and discussions. Findings that relate to answering the research questions were abstracted into an Excel file. Subsequently, a thematic analysis was conducted to identify the themes and subthemes. Thematic analysis was considered the most suitable method for synthesizing the data deriving from a mixed research design (integrative) [27]. The themes were generated through similar patterns that emerged from the abstracted data, while the subthemes emerged when researchers reviewed the themes again.

\section{Results}

\subsection{Overview of the Articles}

Figure 2 shows that 50 papers were published between 2011 and 2020, and the remaining 10 were published between 2000 and 2010, which the earliest paper was published in 2004. Most of the studies adopted a quantitative research methodology (54), while others adopted a qualitative (4) and mixed-method (MM) methodology (2). From the 54 quantitative studies reviewed, nine were based on secondary data from several published statistics, such as the International Social Survey Programme Environment, European Social Survey (ESS), Irish National Election Study, and World Values Survey. The primary data were collected using a questionnaire (telephone, mail, face-to-face, online) or inter- 
views (group discussion, focus group, and individuals). In terms of total respondents, the least number was 12 by Beuermann and Santarius [28] in their qualitative research, and the highest was by Umit and Schaffer [29] and Fairbrother et al. [30] using the ESS data. Many studies (23) had between 1 to 1000 respondents, and only nine studies had a total number of respondents between 2001 to 3000 .

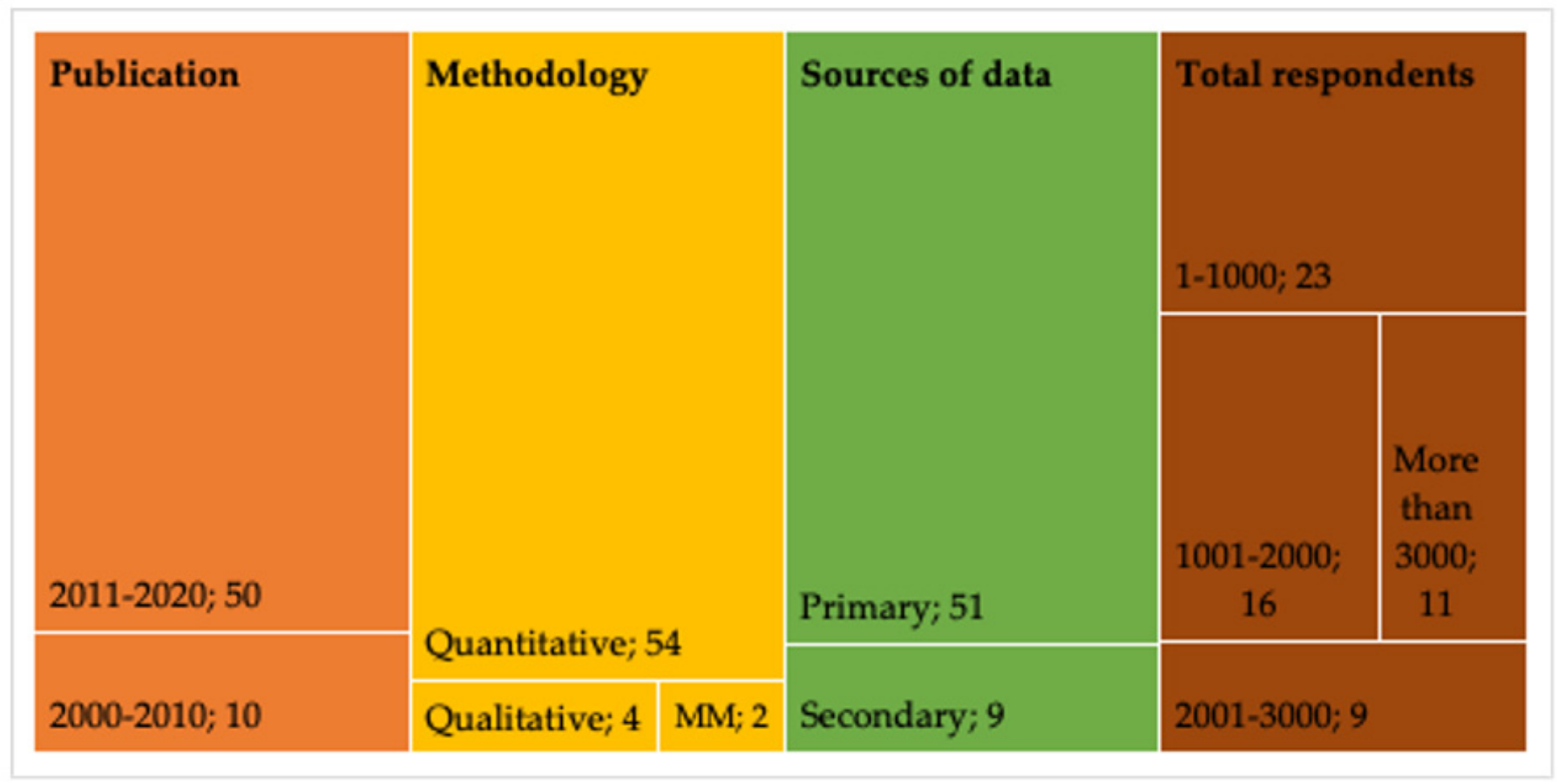

Figure 2. Thematic foci of the review.

Figure 3 shows the type of environmental tax examined. More than half of the studies asked respondents about their acceptance of carbon tax (31), while other studies examined the public acceptance of the general policy of environmental tax (12), vehicle tax (3), energy tax (3), fuel tax (3) and waste charge (2). Types of environmental tax that are seldom tested are gasoline tax, plastic bag fees, congestion charge, city traffic, and water charges.

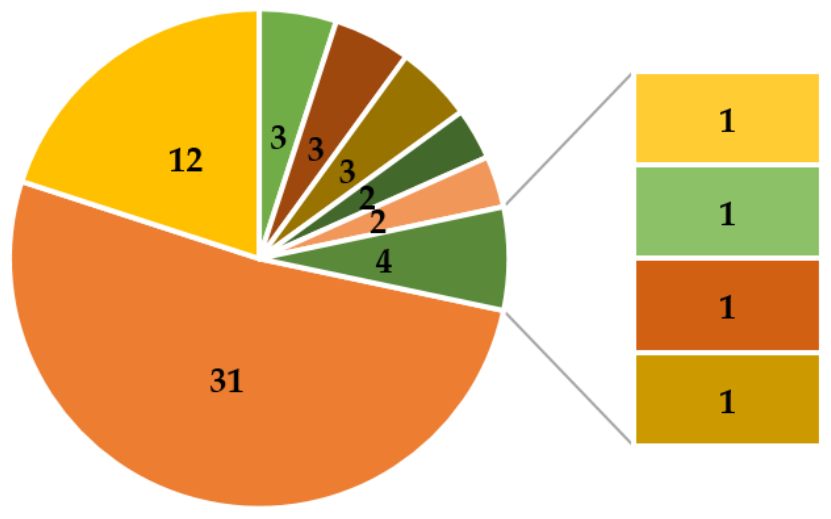

$$
\begin{aligned}
& \text { घ Carbon tax } \quad \text { Environmental tax } \backsim \text { Vehicle tax } \\
& \text { - Energy tax } \\
& \text { - Fuel tax } \\
& \text { - Waste charge } \quad \text { Gasoline tax } \\
& \text { - Plastic bag }
\end{aligned}
$$

Figure 3. Types of taxes examined. 
Figure 4 shows countries covered by the studies. Many studies were derived from the United States (US) (11) and European countries such as Norway (6), Sweden (6), and Switzerland (4). Ten studies gathered data from two or more countries simultaneously; for example, Wicki et al. [31] examined public acceptance from China, Germany, and the US, while Kim and Shin [32] collected data from the US and South Korea. Studies that were based on secondary data examined the public acceptance of environmental tax from 23 European countries [29,30], 30 countries [33], and 51 countries [34].

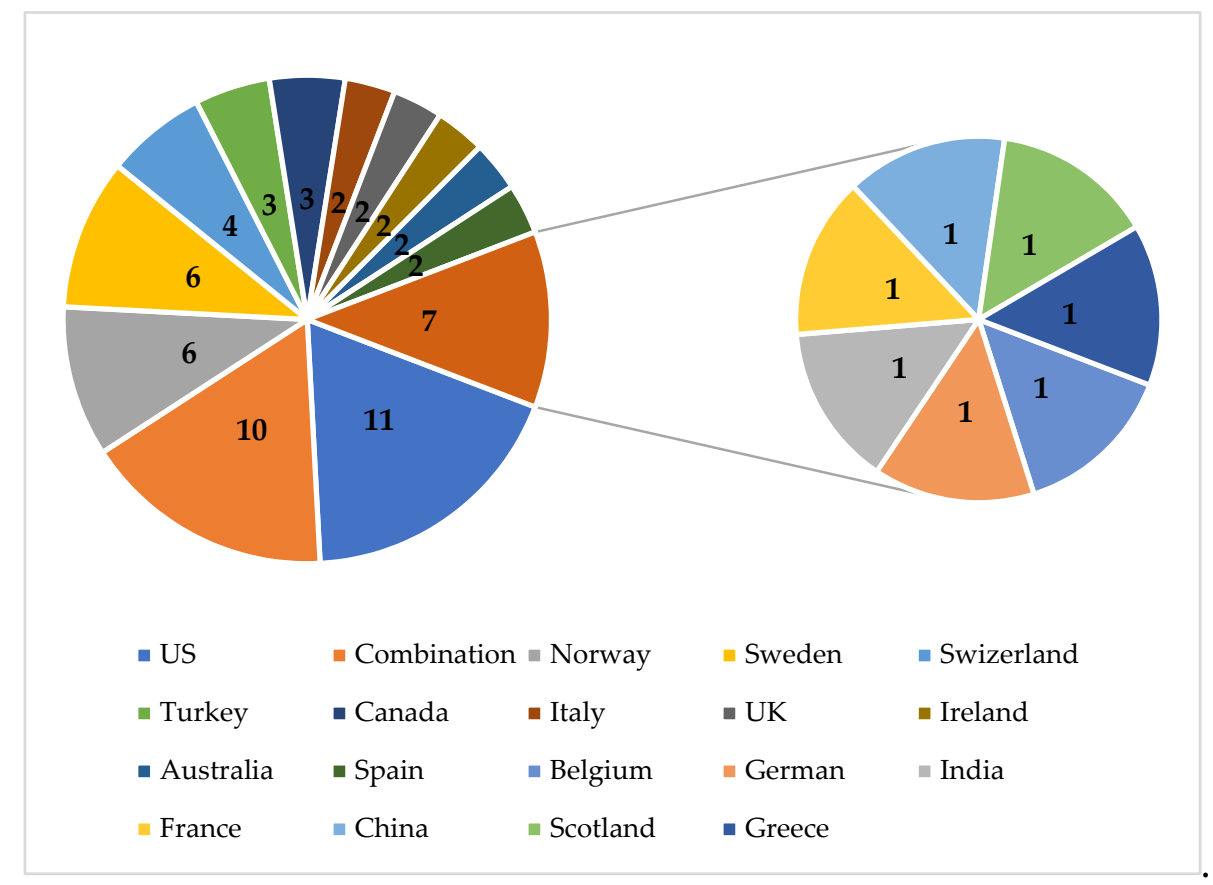

Figure 4. Countries covered by the studies.

\subsection{Measuring of Public Acceptance}

The thematic analysis shows there are similarities and differences in measuring public acceptance. The majority of quantitative studies used direct questions, for example, "Would you accept this carbon tax?", "Is the implementation of such tax acceptable?", "Do you support the environmental tax?" or "If you consider the proposal as a whole, what is your attitude toward the proposal". The choices of answer are between 'yes, no or not sure' (e.g., [35]) or five to seven points of Likert scale from 'strongly disagree to strongly agree' or 'strongly oppose to strongly support' [20,31,36,37]. Rosentrater et al. [38] used a more complex approach by measuring public acceptance with their preference on strategies to reduce climate change, such as planting trees, limiting population growth, and largely replacing fossil fuels with a nuclear strategy. In the study, public support was categorized into 'no-regret approaches', 'behavioral approaches', and 'engineering approaches'. Other studies measured public acceptance based on their WTP for different tax rates or charges, typically adopted in an experimental approach (e.g., [34,39,40]). In qualitative studies, respondents' acceptance response was recorded when they mentioned 'agree', 'support', 'accept', or 'willing to pay' (e.g., [41-43]).

\subsection{Themes and Sub-Themes for Factors That Influence Public Support}

Four main themes were derived from the thematic analysis-policy, governance, personal traits, and demographic. The former has nine sub-themes, and the three latter themes have four, seven, and 12 sub-themes, respectively, shown in Table 2. A list of the 60 papers with their themes and sub-themes is shown in Appendix A. 
Table 2. Themes and Sub-theme for the Factors that Influence Public Support.

\begin{tabular}{cc}
\hline Theme & Sub-Theme \\
\hline Policy & $\begin{array}{c}\text { Type of policy, use of revenue, tax rate, exemption, experience, } \\
\text { competitiveness, cost distribution, information dissemination, and } \\
\text { effectiveness. }\end{array}$ \\
Governance & $\begin{array}{c}\text { Political value orientation, trust in the government, efforts in } \\
\text { protecting the environment, and quality of government (QoG). } \\
\text { Environmental protection attitude, perceived severity of climate } \\
\text { change, psychological, social sharing, health, actual polluters and } \\
\text { visited abroad. }\end{array}$ \\
Demographic traits & $\begin{array}{c}\text { Income, age, education, gender, location, energy dependency, race, } \\
\text { household size, employment, parenthood, religion, and religiosity. }\end{array}$ \\
\hline
\end{tabular}

\subsubsection{Policy}

One of the critical questions for the public is their climate policies preference. A total of 17 studies examined this issue and found public generally do not support taxes over subsidies [44-46], energy investment and low carbon energy investment [36], cap-andtrade [20], voluntarily policies [47] and other command-and-control climate policies [31,38]. Studies in France, Australia, and Sweden show that approximately 70\%, 53\%, and 77\% of respondents respectively would reject carbon tax policy mainly due to perceptions about the policy outcome and overestimation of its impact on purchasing power $[18,48,49]$. People also argued that too many taxes already exist and that a carbon tax is just a new way of taking money out of their pockets [22]. However, Bristow et al. [50] conclude that the public has no unique preference between carbon trading and carbon tax since it depends upon the features of the scheme. A qualitative study by Lo et al. [43] found that the majority of respondents support for the notion of a carbon tax. Those remaining unconvinced expressed their skepticism on its effectiveness and were concerned about the increasing level of personal costs. While respondents in Canada, the Netherlands, Sweden, and Switzerland support the pay-as-you-throw waste charges [51]. The public support could be explained by their concern about the perceived severity of waste generation as a global environmental issue.

In the Policy theme, the use of revenue is the most tested variable, either examined for a direct relationship variable or as a mediating factor variable, with a total of 29 quantitative studies examining its impact on public acceptance. From the 29 quantitative studies, 25 found that the use of revenue has a positive and significant relationship with public support. People give support if the income is recycled back to society $[18,20,52]$ mainly through free health insurance and college tuition [16], measures that facilitate change [17,50,53-55] and reduction in goods and services tax [56]. Earmarking also increased public support [57], primarily when it is used for environmental purposes (e.g., [10,22,58,59]), for example, investing in the development of renewable energy $[20,60]$. However, using environmental tax revenue to reduce corporate and income tax is less acceptable for the public [35,56]. An experimental study by Jagers et al. [61] found that a compensatory measure to the public increased public perceptions of fairness on a carbon tax.

In qualitative studies, people expressed their skepticism toward the idea of using environmental tax revenues to reduce the payroll tax. They would like to see the revenues spent on mitigating environmental damage and financing research and development for green technology because they are concerned about the environmental effects of the tax and do not believe that the tax will improve environmental quality without earmarking $[62,63]$. The respondents also expressed their higher acceptance and support of environmental tax reform by revising the compensation mechanism toward funding for environmental purposes [41]. In contrast, three recent studies by Denstadli and Veisten [64], Uyduranoglu and Ozturk [21], and Wicki et al. [31] conclude that the use of revenue does not play an essential role in obtaining public support. The perception of the effectiveness of carbon taxation may be the reason for this; when the public perceives carbon taxation as an 
effective policy that adequately serves its primary aim, they may not be skeptical of policymakers' motivations for its introduction. Thus, the use of revenues does not influence their support [21].

Studies collectively found a consistent negative effect between tax rate and public acceptance-an increased tax rate is unacceptable to the public, reducing their support and willingness to pay for environmental taxes. The negative effect between the variables supports the economic theory (e.g., [40,50,54,61]). Nowlin et al. [20] suggest that an approximate 81 EUR annual increase for the next ten years will decrease $17 \%$ of public support by 2025. In terms of an exemption, citizens prefer carbon tax policies that do not grant exemptions to domestic or foreign firms; fully taxing these firms significantly increases support for a carbon tax proposal than the baseline of no taxation [40]. Public support also increased when they had experience with the policy, either in a trial run [65] or when the policy was actually being implemented [51]. In terms of competitiveness, public support increased when the policy included a proposal for a job guarantee and retrain fossil fuel workers [16]. For businesses, an environmental policy that persevered local and international competition was a positive and significant factor that influences their support toward environmental tax [10,21]. In contrast, Baranzini and Carattini [66] and Thalmann [55] argue that competitiveness and concern for unemployment did not even play a role in public support.

Individual cost distribution that influences public perceived fairness is an essential factor determining public acceptability for environmental tax. Many studies found a negative and significant relationship-increased individual costs and unfairness perception reduced support (e.g., [10,16,46,48,57]). People who were concerned with income inequality [55] have a negative perception that the policy is designed to obtain more public money [41] and they emphasized that the rich should pay more than the poor [22]. People also perceived that tax as regressive, and people were losing welfare although they could gain from the revenue-neutrality approach. Douenne and Fabre [18] found a non-monotonic relationship, where $30 \%$ of respondents expect the richest to benefit from carbon tax while only $3 \%$ think they will be disadvantaged. On the contrary, $40 \%$ more people believe that the poorest would be disadvantaged rather than benefit, a difference even higher for the middle class - the category most expected to be disadvantaged - at 53\%. Kim et al. [37] suggest that fairness is influenced by trust in government, while Clayton [67] highlights the importance of shared costs and responsibilities. In contrast, Baranzini and Carattini [35] and Fairbrother [52] found that distributional cost fails to impact acceptability. Hammar and Jagers [49] show that public support increase when the equity principal model, which different principles for fair emission reductions are included in carbon tax policy.

A total of 12 studies mutually conclude that information dissemination increased public support that highlighted the complementarity between taxation and communication. The public showed unconditional support and were willing to pay when the government clearly communicated about the effectiveness of policy in reducing emissions [68] and how the revenue will be used (e.g., [40,41,45,66]). Cherry et al. [44] conclude that the language used to describe the policy influences acceptability follows a considerable line of research documenting the impact of labeling and framing of the positive preposition-the more information is provided, more support is given. On a stronger note, Carattini et al. [10] suggest that environmental earmarking may no longer be necessary to receive substantial support for a carbon tax if the information is provided on its environmental effectiveness. Recently, Wicki et al. [31] discovered that announcing and accompanying information campaign increases public support ahead of the implementation as individuals tend to favor policies that provide information in advance. However, information on the timing of implementation date has a relatively small and insignificant relationship with public acceptance.

Studies also show that environmental policy content is often related to public perceptions of its effectiveness in reducing environmental issues, influencing their support. A total of 22 papers collectively agree to a positive relationship between policy support with public perceptions on policy effectiveness in changing the behavior of people and reducing 
emissions (e.g., [21,37,47,48,67]). Baranzini and Carattini [35] found a rise of nearly 30\% for public support when the carbon tax is expected to be effective in reducing carbon emissions. Dreyer and Walker [48] show that when an effective carbon tax is perceived to be high, people equally support the policy regardless of their endorsement of a free-market ideology. On the contrary, the public will not support the policy when they have skepticism about its effects on the environment $[10,41,69]$.

\subsubsection{Governance}

Political value orientation is the most tested variable in the Governance theme, where 23 qualitative studies examined the relationship between partisanship with public acceptability, which indicates tax is a politically related agenda requiring strong support from the public. Many of the studies were conducted in the US and conclusively showed a significant relationship between the variables [32,70,71]. Specifically, Democrats were found to have more support on carbon tax than the Republicans and Independents $[36,53,67,69]$. The support for Democrats increases when carbon tax revenue is recycled to the public [17] by providing health insurance and free college tuition. Their support also increased when the policy includes job guarantee, retraining fossil fuel workers, or offering unionized clean energy jobs [16]. Studies show that the Republicans would rather pay more to protect the environment than passing the carbon tax proposal [69] and give more support if a carbon tax policy includes tax rebate or deficit reduction [20].

Researchers also found mixed results in Switzerland. Using a survey, Baranzini and Carattini [35] conclude that there is no significant relationship between political orientation and public support. Thalmann [55], on the other hand, show that voters who expressed greater affinity with a left-of-center or ecological party voted in a proportion more significant by $35-45 \%$ in favor of the energy tax proposals than those who felt closer to a centrist or right-wing party. Researchers found consistent results in Sweden; Hammar and Jagers [68], Harring and Jagers [72], and Jagers et al. [61] found that respondents considering themselves left-wing are more favorable compared with right-wing respondents and the ones in the middle. In Norway, Grimsrud et al. [58] show that Norwegians who voted Conservative or Progress Party in the last election are more negative toward increased road toll charges, taxes, and road traffic charges. Duan et al. [73] found that political orientation is significantly related to public willingness to pay carbon tax in China-the Communist Party was willing to pay more than those who had a membership with democracy. Using secondary data from 30 countries, Davidovic et al. [33] also found a significant relationship between the variables-people who place themselves more to the left on the left-right scale are more likely to be willing to pay higher taxes for environmental taxes. Although Rotaris and Danielis [60] and Fairbrother [52] found an affiliation between political ideology and public willingness to pay for a carbon tax in Italy and the UK, respectively, it seems that partisanship has little impact on public support. While Kenny [74] and Nastis and Mattas [34] do not find significant relationships between public support and political ideology in Ireland and Greece.

Trust in the government appears to be one of the most important predictors of support, with support increasing monotonically with increases in trust. A total of 19 quantitative studies consistently conclude a positive relationship between the variables (e.g., [22,29,51,72]). Rhodes et al. [47] suggest that trust in the federal government may not be related to public perception of the government ability to manage the tax policy and the use of revenues. However, Hammar and Jagers [68] show that generalized trust does not positively affect the support for an increased carbon tax, but trust in politicians does. In an experimental study, Fairbrother [52] suggests a need to make confidence in the trustworthiness of public officials and their promises more central to conceptualize political trust. Using the same research methodology approach, Sælen and Kallbekken [59] show that those who distrust the government do not favor earmarking more strongly than those who trust it; they are significantly less in favor of the environmental tax. In qualitative studies, respondents in Germany expressed their distrust in political decision-making that they perceived that 
environmental tax reform is not an appropriate instrument to address climate protection objectives [41]. However, the Norwegian respondents have seemingly more trust in the government that they support implementing environmental taxes [62]. Bachus et al. [75] found that the public is willing to pay more when they think that the government is not doing enough to protect the environment; however, their willingness to pay lowers when the government is doing too much to protect the environment. While people in higher levels of Quality of Government (QoG), which refers to the state capacity to perform its activities in an efficient, fair, and impartial manner, and without corruption, are associated with more robust support for environmental taxes compared to those who live in the lower level of QoG [33].

\subsubsection{Personal Traits}

Public perceived severity of climate change, measured by concern, awareness, and knowledge, is the most common variable tested in the personal traits theme with 21 papers. The researchers collectively show that the public gives support to environmental taxes when they understand, are aware, and acknowledged the issue of climate change, the negative impact of climate change on the environment, and causes of climate change (e.g., [38,54,60]). Kotchen et al. [69] found that those who believe global warming is happening are $35 \%$ points more likely to support a carbon tax.

Another common personal trait examined by researchers is the relationship between public support with their attitude toward environmental protection, measured by public environmental behavior and green membership. Except for Duan et al. [73], the other 26 quantitative studies found a positive and significant relationship between the variablesthe more positive attitude toward protecting the environment, the more the public give support for environmental taxes (e.g., [21,32,35]). The public is also more willing to pay for the tax (e.g., [70,76]). The positive relationship is supported by Beuermann and Santarius [41], where the majority of both business representatives and participants of the focus groups stated a willingness to pay for environmental purposes, the prevention of climate change, or the protection of natural resources. In contrast, Convery et al. [42] concluded that there was discernible variation in interviewees' responses related to the degree of environmental awareness.

For social sharing, researchers found that people are more likely to give support when they perceived people in the society provide support to environmental tax implementation [33,39], cooperate in energy conservation's efforts [35,51] and have a fair share of carbon emissions [49]. The policy is also more acceptable people have more trust in other people [72], show more care about a just society [22], and when the carbon tax is framed in terms of collective rather than individual responsibility [67].

Some studies examined individual psychological behavior in determining their support for environmental taxes. Dreyer and Walker [48] conclude that people with high free-market ideology give less support for carbon tax than those with lower free-market ideology. In China, people who were satisfied with their current life were willing to pay higher fees to support carbon tax [73]. A significant relationship was also found between policy support with altruistic, biospheric, and openness to change values [19]. Rhodes et al. [47] also found a positive and significant relationship between high biospheric values with public acceptability for climate policies. Individual preferences regarding carbon taxes may also be substantially driven by personal valuation of the future-people with a high discount rate, which highly value the future compared to the present, are more likely to support a carbon tax [71]. In contrast, Kim et al. [37] do not find a correlation between infringement on freedom with environmental tax support from respondents in the US and UK.

Other personal traits analyzed by researchers are actual polluters [51], health [75], and visits abroad [39]. The former variable was the only variable found to have a significant relationship with public support - those who generate relatively high amounts of mixed waste relative to their peer's view are much less favorable, both in absolute and relative terms, which confirms one hypothesis of the 'rational agent' model [51]. In contrast, 
individual health conditions and whether the respondents have visited abroad do not influence public acceptability.

\subsubsection{Demographic}

Location, income, gender, education, age, and energy dependency are the most tested demographic variables, and researchers found mixed results on their impact on environmental tax support. The majority of studies conclude that people are more likely to give support (e.g., $[60,74,77])$ and are willing to pay tax $[64,75]$ when they have a higher income. Kotchen et al. [69] show that a US\$10,000 increase in a household annual income increases the likelihood of support by a $1 \%$ percentage point. At the same time, Nastis and Mattas [34] confirmed the income elasticity theory-public willingness to pay increases with income from 0.48 for low-income households to 1.40 for high-income households, a quite high variation. Researchers also found that the impact of the revenue-neutrality approach in carbon tax policy is most potent among lower-income groups [16,17]. In contrast, several researchers reported no relationship between income and public support (e.g., [51,52,73]). This is supported by a qualitative study by Convery et al. [42] that concluded there was no discernible variation in these responses related to socio-economic status.

The majority of studies found that gender does not determine public support (e.g., $[68,69,78])$. Others show a significant (with some found a significant but not strong) relationship between the variables with mixed findings between men and women. For example, Agrawal et al. [70], Fairbrother [52], and Rotaris and Danielis [60] show that women give more support than men, while other studies found a contradict result (e.g., $[58,73,79]$ ). Alberini et al. [76] found that men with college-educated hold systematically higher WTP values.

Concerning education, many studies show that opposition to environmental taxes is extreme among less-educated persons, ceteris paribus (e.g., [33,56,57]). Bachus et al. [75] and Baranzini and Carattini [35] show that each additional year of schooling increases WTP and is linked with about $3 \%$ more probability of accepting carbon tax, respectively. Hammar and Jagers [68] and Thalmann [55] define highly educated persons as high school, university degree, and higher professional degree. In contrast, other studies show that education does not relate to public support (e.g., $[36,64,73])$. Although income, gender, and education seem to be important factors, Eliasson and Jonsson [79] conclude that once car dependency, environmental concerns, and perceived effects are controlled, the influence of the demographic factors all but vanished.

The number of papers that found significant results between age and public support is more than insignificant with 13 and eight papers, respectively. The majority of studies show that younger people give more support than older citizens (e.g., $[31,60,68])$. In contrast, Agrawal et al. [70], Amdur et al. [71], and Thalmann [55] found the older people have more support toward environmental taxes. At the same time, Hammar and Jagers [68] explains that the 31-60 age group is more negative than other age groups.

Studies also found mixed results between public support and locations (city, state, or country). While Brown and Johnstone [51], Fairbrother [52], and Hammar and Jagers [68] found no difference between people living in the city and suburb, eight other studies show a significant relationship between the variables $[29,49,55,58,60,79,80]$. Except for Umit and Schaffer [29], the other seven studies consistently found that people in the suburbs or rural areas tend to be less supportive, which may be due to their high dependency on cars. Higher support from people in the city is probably because urban residents are more likely to be exposed to air pollution caused by road transport and favor fiscal policies to reduce gasoline and diesel consumption [60].

In terms of regional, Adaman et al. [39] and Thalmann [55] found no difference between regions in Turkey and Switzerland, respectively. In contrast, Duan et al. [73] and Long et al. [19] show significant differences between regions in China, Canada and California. In China, people from Beijing are more willing to pay for carbon tax than those from Shanghai and Shandong and higher than those from Fujian. While in Canada 
and California, support for carbon tax tends to be higher in Quebec, Ontario, and British Columbia than in Alberta and California. Another study in Canada by Hsu [78] shows that residents in the greenest jurisdictions do not explain public support.

Four studies examined public support differences between countries that only Davidovic et al. [33] found that the country-level control variables did not turn out to be significant. Beiser-McGrath and Bernauer [40] show that German citizens support for carbon tax proposals more than people in other European Union countries or all industrialized countries. In contrast, carbon taxes imposed by other countries do not generate significant increases in support for the US respondents. Fairbrother et al. [30] show that about $7 \%$ of the overall variance in the outcome variable is between the 23 countries examined. Kim and Shin [32] found a significant difference between the American and Korean respondents-for Americans, perceived individual responsibility did not mediate the relationships between environmental concern and tax policy support, and perceived severity and tax policy support. In contrast, for Koreans, perceived individual responsibility fully mediated these beliefs-policy support relationships. Such differences suggest that emphasizing individuals' responsibility for pro-environmental actions is fundamental in encouraging Koreans to engage in environmentally conscious behaviors.

Energy dependency is measured by the type of vehicle used, the number of vehicles owned, and the frequency of vehicle use. Many studies found a negative relationship between the variables-people with higher energy dependency are likely to have less support for the environmental taxes (e.g., [19,49,58]). In contrast, Kallbekken and Aasen [62] and Kim et al. [37] do not find the influence of energy dependency on public support. Rotaris and Danielis [60] found mixed results-owning a car significantly increases the WTP for a carbon tax, while regularly using it to commute negatively influences the WTP.

Studies also show mixed results between race, household size, employment status, and parenthood with public support. All studies that examined the impact of race on public support were conducted in the US which only Feldman and Hart [36] found a non-significant result. Agrawal et al. [70] conclude that white voters were less likely than non-whites to support environmental taxes. In contrast, Amdur et al. [71] show that nonwhite individuals are significantly less likely to support a carbon tax than Caucasians. A carbon tax policy that includes health insurance and free college builds more support for African Americans and Hispanics than white [16]. While Birol and Das [77], Kenny [74], Migheli [80], and Thalmann [55] found populations with a higher number of households give less support for environmental taxes, Brown and Johnstone [51] and Kotchen et al. [69] show no relationship between the variables. Birol and Das [77] and Kenny [74] found contradictory results between employability and public acceptability for wastewater charges, with the former show a significant relationship.

Parents are less willing than non-parents to give part of their income to the environment. However, as the number of children increases, so does environmental concern [80]. In a more recent study, Uyduranoglu and Ozturk [21] parents were more likely to support a carbon tax. Nevertheless, Adaman et al. [39] and Bachus et al. [75] do not find a statistically significant relationship between parenthood and public support. While Amdur et al. [71] show that religion influences public support-non-Christians are significantly more likely to support a carbon tax than Christians-Bachus et al. [75] do not find a significant difference in religiosity.

\section{Discussions}

Table 3 shows the four main themes and 32 sub-themes derived from the thematic analysis. The analysis indicates that people are more supportive when they (i) are well informed about its effectiveness and the policy content, particularly the use of revenue, (ii) have high trust in the government (iii) have a positive attitude in protecting the environment (iv) perceived the policy is fair in terms of costs distribution and social sharing and (v) concern about climate change issue. Other demographic factors may not significantly influence public acceptability for environmental taxes except for energy dependency. Re- 
gardless, examining demographic factors is vital to assist policymakers in understanding possible public differences and target groups of people who need more information or support in facing changes. The results offer both practical and knowledge contributions.

Table 3. Main theme and sub-themes derived from the thematic analysis.

\begin{tabular}{|c|c|c|c|c|}
\hline Main theme & Policy & Governance & Personal Traits & Demographic \\
\hline Sub-theme & $\begin{array}{l}\text { Use of revenue } \\
\text { Cost distribution } \\
\text { Effectiveness } \\
\text { Type of policy } \\
\text { Tax rate } \\
\text { Information } \\
\text { Dissemination } \\
\text { Competitiveness } \\
\text { Experience } \\
\text { Exemption }\end{array}$ & $\begin{array}{l}\text { Political value } \\
\text { orientation } \\
\text { Trust } \\
\text { Efforts in } \\
\text { protecting the } \\
\text { environment } \\
\text { Quality of } \\
\text { government }\end{array}$ & $\begin{array}{c}\text { Perceived } \\
\text { severity of } \\
\text { climate change } \\
\text { Environmental } \\
\text { protection } \\
\text { attitude } \\
\text { Psychological } \\
\text { Social sharing } \\
\text { Good health } \\
\text { Actual polluter } \\
\text { Visited abroad }\end{array}$ & $\begin{array}{c}\text { Location } \\
\text { Income } \\
\text { Gender } \\
\text { Education } \\
\text { Age } \\
\text { Energy } \\
\text { dependency } \\
\text { Household size } \\
\text { Parenthood } \\
\text { Race } \\
\text { Employment } \\
\text { Religion } \\
\text { Religiosity }\end{array}$ \\
\hline
\end{tabular}

\subsection{Implications to the Policy and Practice}

Information dissemination to the public should be a top priority to policy makers. An informed public will raise awareness, improve feasibility, enhance trust, and garner public support toward environmental taxes. Policy makers must be transparent in communicating all aspects of the policy particularly revenue allocation, distributional implications, and how they intend to address them. Public support could be gained through public dialogues with affected stakeholders and incorporates their feedback into the policy. Furthermore, positive environmental attitudes should be inculcated and started from young age through campaigns in social media and education syllabus.

Studies on public acceptability should be conducted on the pre-and post-implementation of environmental tax policy to facilitate governments in several ways [8]. In the preimplementation study, governments can gather public awareness of environmental protection and their willingness to pay environmental tax. Such understanding can assist governments in building relevant strategies to inculcate positive attitudes and avoid hasty rejections through formal education and knowledge dissemination using mass media. In post-implementation studies, governments can understand changes in public attitudes, measure policy effectiveness, and identify weaknesses. Given these advantages, countries planning the implementation of environmental tax policy should conduct both pre-and post-implementation studies.

As environmental taxes have been receiving more attention in developing countries, more studies should focus on strategies to gain public support. Generally, developing countries have common social and economic issues such as insufficient income and resources, social inequity, and poverty that make the implementation of environmental taxes more complicated. Carattini et al. [81] explained four basic methods-phasing in carbon taxes over time, earmarking, fair cost distribution, and information sharing - to increase support toward a carbon tax. However, gaining support from people in developing countries should focus from the initial stage of designing the policy (e.g., subsidy reform, objective, tax rate, tax base, use of revenue, and coordination with other tax policies) until the policy is fully implemented. A carefully designed policy following the country's fiscal, social, and economic conditions will ensure its effectiveness with lower chances of being rejected by the public. Rejection by the public can instantly abolish the policy that significantly damages the government in terms of monetary, resources, and time.

Countries that have not implemented environmental tax should consider this policy, particularly during the pandemic crisis where economic recovery packages provide an opportunity to decarbonize society and widen the government's tax base. The efficiency 
of environmental tax may not be seen in immediate effect, but citizens will recognize its significant benefits to social, economic, and fiscal developments in a few years. Its implementation undeniably involves several years of preparation for research, knowledge dissemination, and commitment from several related ministries.

\subsection{Suggestions for Future Research}

Trust in the government has been one of most tested variables by researchers. The majority of studies measured government trust using the following questions: "Do you trust the government?", "Do you trust the politicians?" and "Do you trust the parliament?". Their findings were consistent: the public generally does not trust the government. This finding coincides with the report from the OECD [82] that trust in government is deteriorating in many OECD countries; only $45 \%$ of citizens trusted their government. Future research should not use general questions to measure trust in the government because the result will not contribute new knowledge to the study area. Instead, researchers should focus on the predictors of government trust, such as responsiveness, reliability, integrity, openness, and fairness [80].

Explanations as to why the public does not trust the government need to be gathered because the government does not respond to public grievances; is it because the government is not transparent, or is it because the government fails to manage public funds? The report from the OECD [82] also indicates that trust may no longer be an essential variable in environmental tax-public acceptance study because people generally will not accept any government's decisions. Furthermore, governments concerned about climate change and understand the positive impact of an environmental tax on social economics will implement the policy despite the public's rejection. Future research should specify why trust in the government should be examined further, and such a study is different from other studies.

Future studies should also examine other variables such as how people perceive current economic conditions and tax morale. Human behavior and environmental tax should be better understood by testing variables from fiscal psychology and the theory of planned behavior, which are often used in tax compliance studies.

\section{Conclusions}

Many international organizations encourage governments to implement environmental taxes to change people environmental behavior and generate additional revenues to improve citizens lives. Nevertheless, the policy is unpopular and unfavorable to the public. Using the ROSES protocol, this study systematically reviewed empirical studies on public acceptance of environmental tax.

Using Scopus and Science Direct databases, as well as Google Scholar, a total of 60 related articles were retrieved. The analysis shows that the majority of the studies adopted the quantitative research methodology through survey questionnaires and experimental approaches. The most tested variables are the use of revenue, environmental attitude, political ideology, trust in the government, and perceived policy effectiveness. Researchers also commonly examine income, age, education, gender, and location for the demographic factor, and they found mixed results.

A thematic analysis was conducted on the articles that derived four main themes with 32 sub-themes. In the analysis, it was revealed that people give support to a carbon tax when they (i) are aware of its efficacy and the policy content, mainly the use of revenue, (ii) believe that the government is trustworthy, (iii) have a positive attitude in environmental protection, (iv) perceive the policy is fair in terms of costs distribution and social sharing, and (v) are concern about climate change issues. The analysis shows that information dissemination to the public is vital to raise awareness, improve feasibility, and garner public support. Policy makers must communicate all aspects of their policies including revenue allocation, distributional implications, and how they intend to address them, in a clear and concise manner. 
This study also facilitates researchers to understand variables that have been tested in environmental tax-public acceptance studies from 2000 to 2020. In generating new knowledge to this study area, future research on trust to the government should focus on other predictors of government trust such as responsiveness, reliability, integrity, openness, and fairness. Future studies may also include new variables, including the public's understanding of the current economic status, tax morale, and religiosity. Variables from fiscal-psychological theory and the theory of planned behavior, which have often been adopted in tax compliance studies, should be tested to understand human behavior and environmental tax better.

Author Contributions: Conceptualization, I.M.; methodology, I.M.; validation, I.M. and N.N.M.H.; formal analysis, I.M.; resources, I.M. and N.N.M.H.; writing-original draft preparation, I.M.; writing-review and editing, I.M., N.N.M.H. and P.E.; visualization, I.M.; supervision, P.E. All authors have read and agreed to the published version of the manuscript.

Funding: This research was funded by the Malaysian Ministry of Higher Education, grant number FRGS/1/2019/SS01/USIM/03/2.

Conflicts of Interest: The authors declare no conflict of interest. The funder had no role in the design of the study; in the collection, analyses, or interpretation of data; in the writing of the manuscript, or in the decision to publish the results. 


\section{Appendix A}

Table A1. List of paper analyzed, themes and sub-themes.

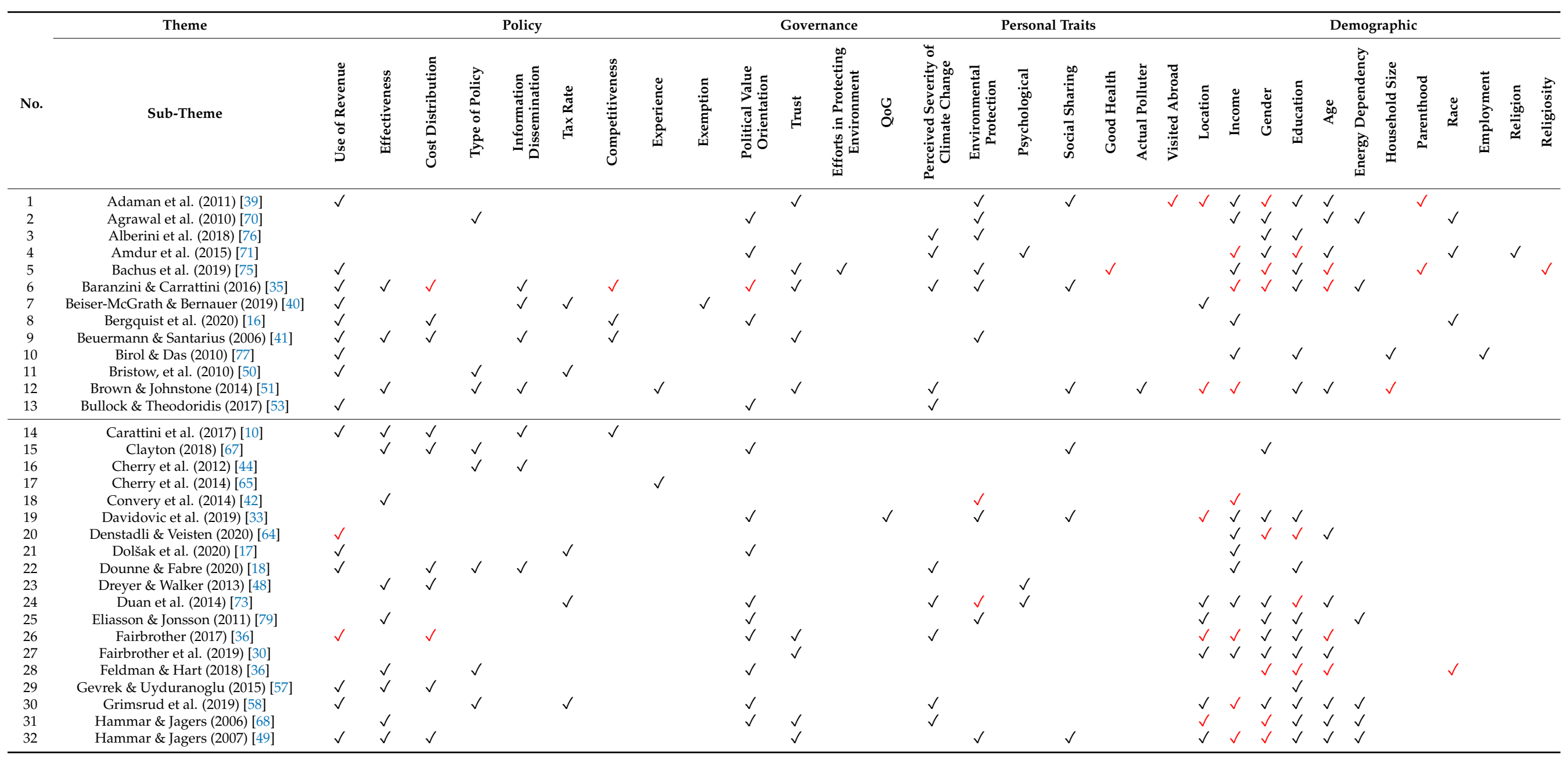


Table A1. Cont.

\begin{tabular}{|c|c|c|c|c|c|c|c|c|c|c|c|c|c|c|c|c|c|c|c|c|c|c|c|c|c|c|c|c|c|c|c|c|c|c|c|}
\hline \multirow[b]{2}{*}{ No. } & \multirow{2}{*}{$\begin{array}{c}\text { Theme } \\
\text { Sub-Theme }\end{array}$} & \multicolumn{9}{|c|}{ Policy } & \multicolumn{4}{|c|}{ Governance } & \multicolumn{7}{|c|}{ Personal Traits } & \multicolumn{14}{|c|}{ Demographic } \\
\hline & & 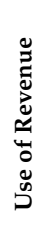 & 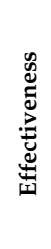 & 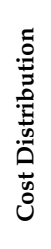 & 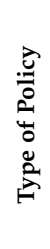 & 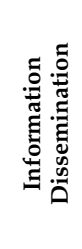 & 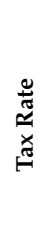 & 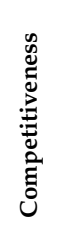 & 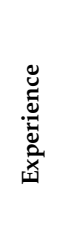 & 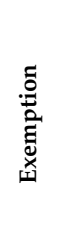 & 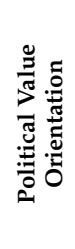 & 苾 & 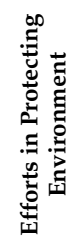 & $\begin{array}{l}\text { Oे } \\
\text { a }\end{array}$ & 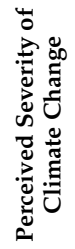 & 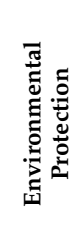 & 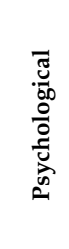 & 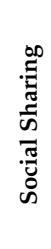 & 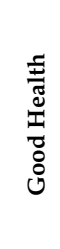 & 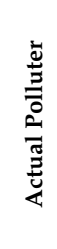 & 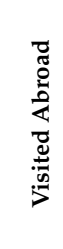 & 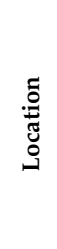 & 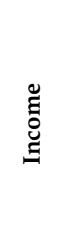 & 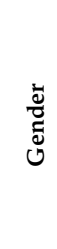 & 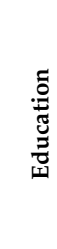 & . & & 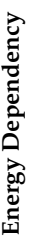 & 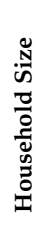 & 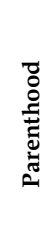 & & & 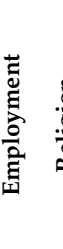 & & 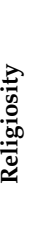 \\
\hline 33 & Harring \& Jagers (2013) [72] & & & & & & & & & & $\checkmark$ & $\checkmark$ & & & & $\checkmark$ & & $\checkmark$ & & & & $\checkmark$ & $\checkmark$ & & & & & $\checkmark$ & & & & & & & \\
\hline 34 & Heres et al. (2017) [45] & & $\checkmark$ & & $\checkmark$ & $\checkmark$ & & & & & & & & & & & & & & & & 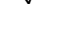 & & & & & & & & & & & & & \\
\hline 35 & Hsu (2010) [78] & $\checkmark$ & & & & & & & & & & $\checkmark$ & & & & & & & & & & $\checkmark$ & $\checkmark$ & $\checkmark$ & $\checkmark$ & $\checkmark$ & & $\checkmark$ & & & & & & & \\
\hline 36 & Hsu et al. (2008) [56] & $\checkmark$ & & & & & & & & & & & & & & & & & & & & & $\checkmark$ & $\checkmark$ & $\checkmark$ & & & $\checkmark$ & & & & & & & \\
\hline 37 & Jagers \& Hammar (2009) [46] & & $\checkmark$ & $\checkmark$ & $\checkmark$ & & & & & & & & & & & & & & & & & & & & & & & & & & & & & & \\
\hline 38 & Jagers et al. (2018) [61] & $\checkmark$ & & $\checkmark$ & & & $\checkmark$ & & & & $\checkmark$ & & & & & & & & & & & & & & & & & & & & & & & & \\
\hline 39 & Kallbekken \& Aasen (2010) [62] & $\checkmark$ & & & & $\checkmark$ & & & & & & $\checkmark$ & & & & & & & & & & & & & & & & & & & & & & & \\
\hline 40 & Kallbekken \& Sæælen (2011) [63] & & $\checkmark$ & & & & $\checkmark$ & & & & & $\checkmark$ & & & $\checkmark$ & & & & & & & & $\checkmark$ & $\checkmark$ & $\checkmark$ & & & $\checkmark$ & & & & & & & \\
\hline 41 & Kenny (2019) [74] & & $\checkmark$ & $\checkmark$ & & & & & & & $\checkmark$ & & & & & & & & & & & & $\checkmark$ & & & & & & $\checkmark$ & & & & $\checkmark$ & & \\
\hline 42 & Kim et al. (2013) [37] & & $\checkmark$ & $\checkmark$ & & & & & & & & $\checkmark$ & & & $\checkmark$ & & $\checkmark$ & & & & & & & $\checkmark$ & & & & $\checkmark$ & & & & & & & \\
\hline 43 & Kim \& Shin (2015) [32] & & & & & & & & & & $\checkmark$ & & & & $\checkmark$ & $\checkmark$ & & & & & & $\checkmark$ & & & & & & & & & & & & & \\
\hline 44 & Kotchen et al. (2017) [69] & $\checkmark$ & & & & & $\checkmark$ & & & & $\checkmark$ & & & & $\checkmark$ & & & & & & & & $\checkmark$ & $\checkmark$ & $\checkmark$ & $\checkmark$ & & & $\checkmark$ & & & & & & \\
\hline 45 & Lo et al. (2013) [43] & & & & $\checkmark$ & $\checkmark$ & & & & & & & & & & & & & & & & & & & & & & & & & & & & & \\
\hline 46 & Long et al. (2020) [19] & & & & & & & & & & & $\checkmark$ & & & $\checkmark$ & $\checkmark$ & $\checkmark$ & & & & & $\checkmark$ & $\checkmark$ & $\checkmark$ & $\checkmark$ & $\checkmark$ & & $\checkmark$ & & & & & & & \\
\hline 49 & Nastis \& Mattas (2018) [34] & & & & & & & & & & $\checkmark$ & & & & $\checkmark$ & & & & & & & & $\checkmark$ & $\checkmark$ & & & & & & & & & & & \\
\hline 50 & Nowlin et al. (2020) [20] & $\checkmark$ & & & $\checkmark$ & & & & & & $\checkmark$ & & & & & & & & & & & & & & & & & & & & & & & & \\
\hline 51 & Rhodes et al. (2017) [47] & & $\checkmark$ & & $\checkmark$ & & & & & & . & $\checkmark$ & & & $\checkmark$ & $\checkmark$ & $\checkmark$ & & & & & $\checkmark$ & $\checkmark$ & $\checkmark$ & $\checkmark$ & $\checkmark$ & & $\checkmark$ & & & & & & & \\
\hline 52 & Rotaris \& Danielis (2019) [60] & $\checkmark$ & & & & & & & & & $\checkmark$ & & & & $\checkmark$ & $\checkmark$ & & & & & & $\checkmark$ & $\checkmark$ & $\checkmark$ & & $\checkmark$ & & $\checkmark$ & & & & & & & \\
\hline 53 & Rosentrater et al. (2013) [38] & & & & $\checkmark$ & & & & & & & & & & $\checkmark$ & $\checkmark$ & & & & & & & & & & & & & & & & & & & \\
\hline 54 & Sælen \& Kallbekken (2011) [59] & $\checkmark$ & $\checkmark$ & & & & $\checkmark$ & & & & & $\checkmark$ & & & & & & & & & & & & & & & & & & & & & & & \\
\hline 55 & Savin et al. (2020) [22] & $\checkmark$ & & $\checkmark$ & $\checkmark$ & & & & & & & $\checkmark$ & & & & $\checkmark$ & & $\checkmark$ & & & & & & & & & & & & & & & & & \\
\hline 56 & Thalmann (2004) [55] & $\checkmark$ & $\checkmark$ & $\checkmark$ & & & $\checkmark$ & $\checkmark$ & & & $\checkmark$ & $\checkmark$ & & & & & & & & & & $\checkmark$ & $\checkmark$ & $\checkmark$ & $\checkmark$ & $\checkmark$ & & $\checkmark$ & $\checkmark$ & & & & & & \\
\hline 57 & Umit \& Schaffer (2020) [29] & & $\checkmark$ & & & & & & & & & $\checkmark$ & & & & & & & & & & $\checkmark$ & & & & & & $\checkmark$ & & & & & & & \\
\hline 58 & Uyduranoglu \& Ozturk (2020) [21] & $\checkmark$ & $\checkmark$ & $\checkmark$ & & & & $\checkmark$ & & & & & & & $\checkmark$ & & & & & & & & $\checkmark$ & $\checkmark$ & $\checkmark$ & & & & & $\checkmark$ & & & & & \\
\hline 59 & Wicki et al. (2019) [31] & $\checkmark$ & & & $\checkmark$ & $\checkmark$ & & & & & & & & & & & & & & & & $\checkmark$ & & & & & & & & & & & & & \\
\hline \multirow[t]{2}{*}{60} & Wicki et al. (2020) [23] & $\checkmark$ & & & $\checkmark$ & $\checkmark$ & & & & & & & & & & & & & & & & & & $\checkmark$ & $\checkmark$ & $\checkmark$ & & $\checkmark$ & & & & & & & \\
\hline & Total & 31 & 22 & 18 & 17 & 12 & 11 & 6 & 2 & 1 & 23 & 21 & 1 & 1 & 21 & 18 & 6 & 8 & 1 & 1 & 1 & 31 & 30 & 30 & 28 & 21 & 1 & 17 & 6 & 4 & 4 & & 2 & 1 & 1 \\
\hline
\end{tabular}




\section{References}

1. Fullerton, D.; Leicester, A.; Smith, S. Environmental Taxes. In Institute for Fiscal Studies (ed) Dimensions of Tax Design; Oxford University Press: Oxford, UK, 2010; pp. 428-549.

2. OECD. Aligning Policies for a Low-Carbon Economy; OECD Publishing: Paris, France, 2015.

3. United National Framework Convention on Climate Change (UNFCCC). Paris Agreement. Available online: https://unfccc.int/ sites/default/files/english_paris_agreement.pdf. (accessed on 10 August 2021).

4. Aldy, J.E.; Stavins, R.N. The Promise and Problems of Pricing Carbon: Theory and Experience. J. Environ. Dev. 2012, 21, 152-180. [CrossRef]

5. OECD. Taxing Energy Use for Sustainable Development; OECD Publishing: Paris, France, 2021.

6. Baranzini, A.; Caliskan, M.; Carattini, S. Economic Prescriptions and Public Responses to Climate Policy. SSRN Electron. J. 2014, 3, $1-19$.

7. OECD; World Bank. The FASTER Principles for Successful Carbon Pricing: An Approach Based on Initial Experience; OECD: Washington, DC, USA, 2015.

8. Partnership for Market Readiness. Carbon Tax Guide: A Hand Book for Policy Makers; World Bank: Wanshington, DC, USA, 2017.

9. Heine, D.; Black, S. Benefits beyond Climate: Environmental Tax Reform. In Fiscal Policies for Development and Climate Action; Wanshington, DC, USA, 2019; pp. 1-185. Available online: https://www.researchgate.net/publication/332135012_Benefits_ beyond_Climate_Environmental_Tax_Reform (accessed on 8 October 2021).

10. Carattini, S.; Baranzini, A.; Thalmann, P.; Varone, F.; Vöhringer, F. Green Taxes in a Post-Paris World: Are Millions of Nays Inevitable? Environ. Resour. Econ. 2017, 68, 97-128. [CrossRef]

11. Haddaway, N.R.; Macura, B.; Whaley, P.; Pullin, A.S. ROSES Reporting Standards for Systematic Evidence Syntheses: Pro Forma, Flow-Diagram and Descriptive Summary of the Plan and Conduct of Environmental Systematic Reviews and Systematic Maps. Environ. Evid. 2018, 7, 1-8. [CrossRef]

12. Okoli, C. A Guide to Conducting a Standalone Systematic Literature Review. Commun. Assoc. Inf. Syst. 2015, 37, 879-910. [CrossRef]

13. Gusenbauer, M.; Haddaway, N.R. Which Academic Search Systems Are Suitable for Systematic Reviews or Meta-Analyses? Evaluating Retrieval Qualities of Google Scholar, PubMed, and 26 Other Resources. Res. Synth. Methods 2020, 11, 181-217. [CrossRef]

14. Haddaway, N.R.; Collins, A.M.; Coughlin, D.; Kirk, S. The Role of Google Scholar in Evidence Reviews and Its Applicability to Grey Literature Searching. PLoS ONE 2015, 10, e0138237. [CrossRef]

15. Shaffril, H.A.M.; Samsuddin, S.F.; Samah, A.A. The ABC of Systematic Literature Review: The Basic Methodological Guidance for Beginners. Qual. Quant. 2020, 55, 1319-1346. [CrossRef]

16. Bergquist, P.; Mildenberger, M.; Stokes, L.C. Combining Climate, Economic, and Social Policy Builds Public Support for Climate Action in the US. Environ. Res. Lett. 2020, 15, 1-9. [CrossRef]

17. Dolšak, N.; Adolph, C.; Prakash, A. Policy Design and Public Support for Carbon Tax: Evidence from a 2018 US National Online Survey Experiment. Public Adm. 2020, 98, 905-921. [CrossRef]

18. Douenne, T.; Fabre, A. French Attitudes on Climate Change, Carbon Taxation and Other Climate Policies. Ecol. Econ. 2020, 169, 1-19. [CrossRef]

19. Long, Z.; Axsen, J.; Kitt, S. Public Support for Supply-Focused Transport Policies: Vehicle Emissions, Low-Carbon Fuels, and ZEV Sales Standards in Canada and California. Transp. Res. Part A Policy Pract. 2020, 141, 98-115. [CrossRef]

20. Nowlin, M.C.; Gupta, K.; Ripberger, J.T. Revenue Use and Public Support for a Carbon Tax. Environ. Res. Lett. 2020, 15, 1-11. [CrossRef]

21. Uyduranoglu, A.; Ozturk, S.S. Public Support for Carbon Taxation in Turkey: Drivers and Barriers. Clim. Policy 2020, 20, 1175-1191. [CrossRef]

22. Savin, I.; Drews, S.; Maestre-Andrés, S.; van den Bergh, J. Public Views on Carbon Taxation and Its Fairness: A ComputationalLinguistics Analysis. Clim. Change 2020, 162, 2107-2138. [CrossRef]

23. Wicki, M.; Huber, R.A.; Bernauer, T. Can Policy-Packaging Increase Public Support for Costly Policies? Insights from a Choice Experiment on Policies against Vehicle Emissions. J. Public Policy 2020, 40, 599-625. [CrossRef]

24. Thomas, J.; Noel-Storr, A.; Marshall, I.; Wallace, B.; McDonald, S.; Mavergames, C.; Glasziou, P.; Shemilt, I.; Synnot, A.; Turner, T.; et al. Living Systematic Reviews: 2. Combining Human and Machine Effort. J. Clin. Epidemiol. 2017, 91, 31-37. [CrossRef]

25. Petticrew, M.; Roberts, H. Systematic Reviews in the Social Sciences: A Practical Guide. Couns. Psychother. Res. 2006, 6, 304-305.

26. Whittemore, R.; Knafl, K. The Integrative Review: Updated Methodology. J. Adv. Nurse 2005, 52, 546-553. [CrossRef]

27. Flemming, K.; Booth, A.; Garside, R.; Tunçalp, Ö.; Noyes, J. Qualitative Evidence Synthesis for Complex Interventions and Guideline Development: Clarification of The Purpose, Designs and Relevant Methods. BMJ Glob. Health 2018, 4, 1-9. [CrossRef]

28. Dresner, S.; Dunne, L.; Clinch, P.; Beuermann, C. Social and Political Responses to Ecological Tax Reform in Europe: An Introduction to the Special Issue. Energy Policy 2006, 34, 895-904. [CrossRef]

29. Umit, R.; Schaffer, L.M. Attitudes Towards Carbon Taxes Across Europe: The Role of Perceived Uncertainty and Self-Interest. Energy Policy 2020, 140, 1-7. [CrossRef] 
30. Fairbrother, M.; Johansson Sevä, I.; Kulin, J. Political Trust and the Relationship between Climate Change Beliefs and Support for Fossil Fuel Taxes: Evidence from a Survey of 23 European Countries. Glob. Environ. Chang. 2019, 59, 1-15. [CrossRef]

31. Wicki, M.; Fesenfeld, L.; Bernauer, T. In Search of Politically Feasible Policy-Packages for Sustainable Passenger Transport: Insights from Choice Experiments in China, Germany, and the USA. Environ. Res. Lett. 2019, 14, 1-17. [CrossRef]

32. Kim, S.; Shin, W. Understanding American and Korean Students' Support for Pro-Environmental Tax Policy: The Application of the Value-Belief-Norm Theory of Environmentalism. Environ. Commun. 2015, 11, 311-331. [CrossRef]

33. Davidovic, D.; Harring, N.; Jagers, S.C. The Contingent Effects of Environmental Concern and Ideology: Institutional Context and People's Willingness to Pay Environmental Taxes. Environ. Polit. 2019, 29, 674-696. [CrossRef]

34. Nastis, S.A.; Mattas, K. Income Elasticity of Willingness-to-Pay for a Carbon Tax in Greece. Int. J. Glob. Warm. 2018, 14, 510-524 [CrossRef]

35. Baranzini, A.; Carattini, S. Effectiveness, Earmarking and Labeling: Testing the Acceptability of Carbon Taxes with Survey Data. Environ. Econ. Policy Stud. 2016, 19, 197-227. [CrossRef]

36. Feldman, L.; Hart, P.S. Climate Change as a Polarizing Cue: Framing Effects on Public Support for Low-Carbon Energy Policies. Glob. Environ. Chang. 2018, 51, 54-66. [CrossRef]

37. Kim, J.; Schmöcker, J.D.; Fujii, S.; Noland, R.B. Attitudes towards Road Pricing and Environmental Taxation among US and UK Students. Transp. Res. Part A Policy Pract. 2013, 48, 50-62. [CrossRef]

38. Rosentrater, L.D.; Sælensminde, I.; Ekström, F.; Böhm, G.; Bostrom, A.; Hanss, D.; O'Connor, R.E. Efficacy Trade-Offs in Individuals' Support for Climate Change Policies. Environ. Behav. 2013, 45, 935-970. [CrossRef]

39. Adaman, F.; Karalidotless, N.; Kumbaroĝlu, G.; Or, I.; Özkaynak, B.; Zenginobuz, Ü. What Determines Urban Households' Willingness to Pay for CO2 Emission Reductions in Turkey: A Contingent Valuation Survey. Energy Policy 2011, 39, 689-698. [CrossRef]

40. Beiser-McGrath, L.F.; Bernauer, T. Could Revenue Recycling Make Effective Carbon Taxation Politically Feasible? Sci. Adv. 2019, 5, 1-9. [CrossRef] [PubMed]

41. Beuermann, C.; Santarius, T. Ecological Tax Reform in Germany: Handling Two Hot Potatoes at the Same Time. Energy Policy 2006, 34, 917-929. [CrossRef]

42. Convery, F.; Dunne, L.; Joyce, D. Ireland's Carbon Tax in the Context of the Fiscal Crisis. Cyprus Econ. Policy Rev. 2014, 8, 135-143.

43. Lo, A.Y.; Alexander, K.S.; Proctor, W.; Ryan, A. Reciprocity as Deliberative Capacity: Lessons from a Citizen's Deliberation on Carbon Pricing Mechanisms in Australia. Environ. Plan. C Gov. Policy 2013, 31, 444-459. [CrossRef]

44. Cherry, T.L.; Kallbekken, S.; Kroll, S. The Acceptability of Efficiency-Enhancing Environmental Taxes, Subsidies and Regulation: An Experimental Investigation. Environ. Sci. Policy 2012, 16, 90-96. [CrossRef]

45. Heres, D.R.; Kallbekken, S.; Galarraga, I. The Role of Budgetary Information in the Preference for Externality-Correcting Subsidies over Taxes: A Lab Experiment on Public Support. Environ. Resour. Econ. 2015, 66, 1-15. [CrossRef]

46. Jagers, S.C.; Hammar, H. Environmental Taxation for Good and for Bad: The Effciency and Legitimacy of Sweden's Carbon Tax. Environ. Polit. 2009, 18, 218-237. [CrossRef]

47. Rhodes, E.; Axsen, J.; Jaccard, M. Exploring Citizen Support for Different Types of Climate Policy. Ecol. Econ. 2017, 137, 56-69. [CrossRef]

48. Dreyer, S.J.; Walker, I. Acceptance and Support of the Australian Carbon Policy. Soc. Justice Res. 2013, 26, 343-362. [CrossRef]

49. Hammar, H.; Jagers, S.C. What Is a Fair CO2 Tax Increase? On Fair Emission Reductions in the Transport Sector. Ecol. Econ. 2007, 61, 377-387. [CrossRef]

50. Bristow, A.L.; Wardman, M.; Zanni, A.M.; Chintakayala, P.K. Public Acceptability of Personal Carbon Trading and Carbon Tax. Ecol. Econ. 2010, 69, 1824-1837. [CrossRef]

51. Brown, Z.S.; Johnstone, N. Better the Devil You Throw: Experience and Support for Pay-as-You-Throw Waste Charges. Environ. Sci. Policy 2014, 38, 132-142. [CrossRef]

52. Fairbrother, M. When Will People Pay to Pollute? Environmental Taxes, Political Trust and Experimental Evidence from Britain. Br. J. Polit. Sci. 2017, 49, 661-682. [CrossRef]

53. Bullock, G.; Theodoridis, A.G. Addressing Concerns about Climate Policies: The Possibilities and Perils of Responsive Accommodation. Env. Polit. 2017, 26, 1079-1106. [CrossRef]

54. McLaughlin, C.; Elamer, A.A.; Glen, T.; AlHares, A.; Gaber, H.R. Accounting Society's Acceptability of Carbon Taxes: Expectations and Reality. Energy Policy 2019, 131, 302-311. [CrossRef]

55. Thalmann, P. The Public Acceptance of Green Taxes: 2 Million Voters Express Their Opinion. Public Choice 2004, 119, 179-217. [CrossRef]

56. Hsu, S.L.; Walters, J.; Purgas, A. Pollution Tax Heuristics: An Empirical Study of Willingness to Pay Higher Gasoline Taxes. Energy Policy 2008, 36, 3612-3619. [CrossRef]

57. Gevrek, Z.E.; Uyduranoglu, A. Public Preferences for Carbon Tax Attributes. Ecol. Econ. 2015, 118, 186-197. [CrossRef]

58. Grimsrud, K.M.; Lindhjem, H.; Sem, I.V.; Rosendahl, K.E. Public Acceptance and Willingness to Pay Cost-Effective Taxes on Red Meat and City Traffic in Norway. J. Environ. Econ. Policy 2019, 9, 251-268. [CrossRef]

59. Sælen, H.; Kallbekken, S. A Choice Experiment on Fuel Taxation and Earmarking in Norway. Ecol. Econ. 2011, 70, 2181-2190. [CrossRef] 
60. Rotaris, L.; Danielis, R. The Willingness to Pay for a Carbon Tax in Italy. Transp. Res. Part D Transp. Environ. 2019, 67, 659-673. [CrossRef]

61. Jagers, S.C.; Martinsson, J.; Matti, S. The Impact of Compensatory Measures on Public Support for Carbon Taxation: An Experimental Study in Sweden. Clim. Policy 2018, 19, 147-160. [CrossRef]

62. Kallbekken, S.; Aasen, M. The Demand for Earmarking: Results from a Focus Group Study. Ecol. Econ. 2010, 69, 2183-2190. [CrossRef]

63. Kallbekken, S.; Sæælen, H. Public Acceptance for Environmental Taxes: Self-Interest, Environmental and Distributional Concerns. Energy Policy 2011, 39, 2966-2973. [CrossRef]

64. Denstadli, J.M.; Veisten, K. The Flight Is Valuable Regardless of the Carbon Tax Scheme: A Case Study of Norwegian Leisure Air Travelers. Tour. Manag. 2020, 81, 1-12. [CrossRef]

65. Cherry, T.L.; Kallbekken, S.; Kroll, S. The Impact of Trial Runs on the Acceptability of Environmental Taxes: Experimental Evidence. Resour. Energy Econ. 2014, 38, 84-95. [CrossRef]

66. Doda, B.; Gennaioli, C.; Gouldson, A.; Grover, D.; Sullivan, R. Are Corporate Carbon Management Practices Reducing Corporate Carbon Emissions? Corp. Soc. Responsib. Environ. Manag. 2016, 23, 257-270. [CrossRef]

67. Clayton, S. The Role of Perceived Justice, Political Ideology, and Individual or Collective Framing in Support for Environmental Policies. Soc. Justice Res. 2018, 31, 1-19. [CrossRef]

68. Hammar, H.; Jagers, S.C. Can Trust in Politicians Explain Individuals' Support for Climate Policy? The Case of CO2 Tax Clim. Policy 2006, 5, 613-625. [CrossRef]

69. Kotchen, M.J.; Turk, Z.M.; Leiserowitz, A.A. Public Willingness to Pay for a US Carbon Tax and Preferences for Spending the Revenue. Environ. Res. Lett. 2017, 12, 1-5. [CrossRef]

70. Agrawal, A.W.; Dill, J.; Nixon, H. Green Transportation Taxes and Fees: A Survey of Public Preferences in California Transp. Res. Part D Transp. Environ. 2010, 15, 189-196. [CrossRef]

71. Amdur, D.; Dale, D.; Borick, C.; Rabe, B.G. Individual Discount Rates and Climate Change: Is Discount Rate Associated with Support for a Carbon Tax? Clim. Chang. Econ. 2015, 6, 1-14. [CrossRef]

72. Harring, N.; Jagers, S.C. Should We Trust in Values? Explaining Public Support for pro-Environmental Taxes. Sustainability 2013, 5, 210-227. [CrossRef]

73. Duan, H.X.; Lü, Y.L.; Li, Y. Chinese Public's Willingness to Pay for CO2 Emissions Reductions: A Case Study from Four Provinces/Cities. Adv. Clim. Chang. Res. 2014, 5, 100-110. [CrossRef]

74. Kenny, J. Environmentalism Undercover: The Environmental Dimension of Public Support for Domestic Water Charges. Elect. Stud. 2019, 62, 1-11. [CrossRef]

75. Bachus, K.; Van Ootegem, L.; Verhofstadt, E. 'No Taxation without Hypothecation': Towards an Improved Understanding of the Acceptability of an Environmental Tax Reform*. J. Environ. Policy Plan. 2019, 21, 321-332. [CrossRef]

76. Alberini, A.; Ščasný, M.; Bigano, A. Policy- v. Individual Heterogeneity in the Benefits of Climate Change Mitigation: Evidence from a Stated-Preference Survey. Energy Policy 2018, 121, 565-575. [CrossRef]

77. Birol, E.; Das, S. Estimating the Value of Improved Wastewater Treatment: The Case of River Ganga, India. J. Environ. Manag. 2010, 91, 2163-2171. [CrossRef]

78. Hsu, S.-L. The Politics and Psychology of Gasoline Taxes: An Empirical Study. Widener Law Rev. 2010, 26, 363-390.

79. Eliasson, J.; Jonsson, L. The Unexpected "Yes": Explanatory Factors behind the Positive Attitudes to Congestion Charges in Stockholm. Transp. Policy 2011, 18, 636-647. [CrossRef]

80. Migheli, M. Brown Parents, Green Dads: Gender, Children, and Environmental Taxes. J. Clean. Prod. 2018, 180, 183-197. [CrossRef]

81. Carattini, S.; Carvalho, M.; Fankhauser, S. Overcoming Public Resistance to Carbon Taxes. Wiley Interdiscip. Rev. Clim. Chang. 2018, 9, 1-26. [CrossRef]

82. Organizational for Economic Co-Operation and Development (OECD). Government at a Glance; Organizational for Economic Cooperation and Development (OECD), OECD Publishing: Paris, France, 2019. 